\title{
Analysis of Mesquite (Prosopis juliflora) Protein Concentrate for Possible Use as Supplementary Protein
}

\author{
José Jaimes-Morales, ${ }^{1}$ Yesid A. Marrugo-Ligardo, ${ }^{1}$ and Diofanor Acevedo-Correa $\mathbb{D}^{2}$ \\ ${ }^{1}$ Grupo de Investigación en Medio Ambiente, Alimentos y Salud, Universidad de Cartagena, Campus Zaragocilla, \\ Cartagena de Indias 130015, Colombia \\ ${ }^{2}$ Grupo de Investigación en Innovación y Desarrollo Agropecuario y Agroindustrial (IIDAA), Universidad de Cartagena, \\ Campus Piedra de Bolívar, Cartagena de Indias 130015, Colombia
}

Correspondence should be addressed to Diofanor Acevedo-Correa; dacevedoc1@unicartagena.edu.co

Received 7 September 2021; Revised 4 January 2022; Accepted 9 February 2022; Published 24 February 2022

Academic Editor: Karthik Pothiyappan

Copyright (c) 2022 José Jaimes-Morales et al. This is an open access article distributed under the Creative Commons Attribution License, which permits unrestricted use, distribution, and reproduction in any medium, provided the original work is properly cited.

\begin{abstract}
Vulnerable populations in developing countries need new protein sources, such as protein concentrates from accessible sources at low economic costs. The main objective of this study was at evaluating the nutritional quality of the protein concentrate of the legume mesquite (Prosopis juliflora), compared with the protein values of other legumes described in literature. For this purpose, flour and protein concentrates from mesquite were obtained, along with their chemical composition. Amino acid profiling was performed by high-performance liquid chromatography (HPLC). Protein quality index evaluation tests were also performed on preschool children and adults. The protein content of mesquite was found to be $68 \%$. However, mesquite covers the requirements of essential amino acids, surpassing $31 \%$ of the protein required in adults, except for cysteine sulfur amino acids and aromatic amino acids. In other age groups such as children, mesquite had a high content of histidine, which is necessary and considered essential during infant development. According to the above, mesquite could be used as an alternative protein to produce food with high nutritional content.
\end{abstract}

\section{Introduction}

The food security of the population is still affected by malnutrition in many regions of the world, especially in developing countries in Africa, Asia, and Latin America [1-4]. In these areas of the planet, the lack of access to food is growing at an accelerated rate, with the most vulnerable populations requiring mainly protein sources. In this context, dietary protein requirements are affected by the high cost of traditional protein sources, due to the high import rates of legumes such as soybeans, and the lack of native vegetable production $[5,6]$.

Due to the crisis caused by the COVID-19 pandemic, the current and future states of sustainable food security have worsened. Rising food prices, disruptions in supply chains, and limited access to food [7-9] have exacerbated these issues even more. Alternative food sources need to be available and accessible to overcome the issues related to the lack of access to foods of high nutritional value. Some of the most promising solutions are those that can be obtained from plant sources, such as cereals, fruits, legumes, and vegetables. Many of the food sources currently being studied as unique sustenance alternatives are deficient in some vitamins; however, they can be complemented with the consumption of other species, which must be subjected to processing to be digestible and absorbable by the human metabolism [10-12].

Balance between dietary supply and protein needs is also important, as it is vital for maintaining the health and wellbeing of the population. To this end, alternative sources of protein should be explored in areas that require it, investigating the quality of proteins from native plant species that meet the required nutritional value and thus transition to more sustainable plant diets $[5,13]$. Legumes fit into this type of diet since they have beneficial nutritional properties in terms of their high protein content and good amino acid 
profile, thus being an important source for human nutrition, especially in low-income communities. In their composition, their protein values range depending on the species from $17 \%$ to $40 \%$, with even higher amounts of carbohydrates, and variable oil content, normally from $1 \%$ to $6 \%$. Soybeans, beans, chickpeas, and lentils are the most relevant in terms of production volumes, market value, and nutritional value $[14,15]$. Regarding the protein potential of their seeds, legumes have gained importance in the food industry as ingredients in dietary nutritional formulas, meat alternative products $[13,14]$, animal feed, vegetable oil, and protein concentrate $[16,17]$.

The Prosopis genus comprises 44 species of nitrogenfixing trees that grow mainly in arid or semiarid regions of the Americas. Prosopis pods are sweet fruits consisting of $70 \%-75 \%$ pericarp (epicarp, mesocarp, and endocarp) and 25\%-30\% seeds (episperm, endosperm, and cotyledons). The whole ripe pods of the mesquite are ground to produce flour, known as mesquite or carob flour, characterized by its brown color, and coffee-like aroma [18].

The nutrient content and protein digestibility of mesquite flour varies according to its variant. In addition, mesquite flour has been reported to be a good source of lysine, sulfur-containing type of amino acids (Glu, Arg, Asp, and Leu), and total phenolic compounds with increased antioxidant capacity [19].

The ripe fruit of this legume is a seed pod with high nutritional value. The seeds are found in the wild and have low commercial value. It is a legume of the bean, pea, caraota, and quinchoncho family, Mimosaceae [20-23]. The protein of mesquite constitutes $60 \%$ of the weight of the seeds, but for animals to benefit from it, the pods and seeds must be crushed; otherwise, they pass through the digestive tract without being digested. Crushing is difficult because of the presence of a thick pulp surrounding the seed [24, 25].

The nutritional, physicochemical, and biological characteristics of mesquite promote it as a new source of proteins, which make it possible to increase the supply and make high-protein foods available to the population at more affordable prices $[19,26,27]$. The use of protein concentrates from native plant species such as mesquite for possible addition as a nutritional ingredient is an opportunity to provide the community with a food alternative of great impact on nutritional problems and promote the production of this native plant that needs more technical cultivation methods.

Considering the information available on mesquite and its possible use as a protein source, the objective of this study was to evaluate the quality of protein present in mesquite concentrate as a food with high nutritional content, comparing it with that of the soybean, which is a well-known legume used by the food industry.

\section{Materials and Methods}

2.1. Sample Collection. $800 \mathrm{~g}$ of mesquite seeds (see Figure 1) was collected and studied in good physical conditions of development, state of maturity, and phytosanitary hygienic conditions. The mesquite was collected from Cerro de la Popa, located in the city of Cartagena de Indias, Colombia.

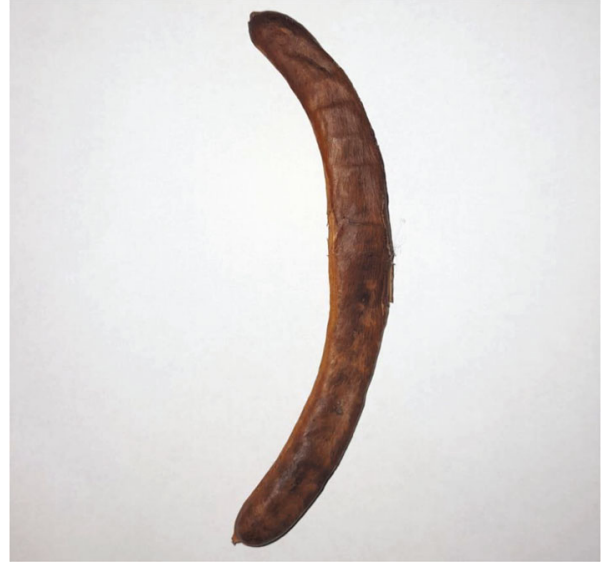

Figure 1: Mesquite used in this work.

2.2. Obtaining Integral Concentrate from Mesquite Seeds. The procedure proposed by Jaimes-Morales et al. [24] was followed to obtain whole mesquite flour. The concentrate was made from pods in good physical and hygienic phytosanitary conditions, then milled, and passed through $1 \mathrm{~mm}^{2}$ no. 2 and no. 3 filters, thus obtaining fine integral concentrate, free of unwanted residues.

2.3. Obtaining Mesquite Protein Concentrates. To obtain the mesquite protein concentrate, the Soxhlet method was used under moderate thermal conditions not exceeding $40^{\circ} \mathrm{C}$, in an attempt to preserve the nutritional properties of the proteins. The defatted flour was subjected to flour-water suspensions in a 1:8 ratio. In the extraction of soluble carbohydrates and mineral salts, the $\mathrm{pH}$ was adjusted to 8 using $\mathrm{NaOH} 1 \mathrm{~N}$. These suspensions were centrifuged at $300 \mathrm{rpm}$ and $40^{\circ} \mathrm{C}$ for $30 \mathrm{~min}$. At the end of the extraction period, the mixture was left to rest, removing the supernatant and the amylaceous residue. Then, the procedure was repeated. The supernatants of the washes and the protein extract were collected in a $50 \mathrm{~mL}$ beaker. The extract was acidified with $1 \mathrm{~N} \mathrm{HCl}$ until the precipitation point of most of the proteins was reached at $\mathrm{pH}$ 5.5. The protein extract was kept at $37^{\circ} \mathrm{C}$ and then subjected to shaking at $300 \mathrm{rpm}$ for $30 \mathrm{~min}$ through centrifugation. Finally, the proteins were separated from the serum by decantation and washed with water under constant mixing. To obtain the protein coagulum, it was subjected to decantation and vacuum drying.

2.4. Comparison of Chemical Composition of Mesquite. The chemical components of the protein concentrates were determined as follows. For the mesquite concentrate, the methodology of Sarmiento et al. [26] and the AOAC (2003) [28] were used. The factors determined were moisture, fiber, ash, fat, and protein. These values were added and subtracted from 100, and the difference was taken as the carbohydrate content.

2.5. Determination of Essential Amino Acids in Mesquite. The determination of amino acids was made by highperformance liquid chromatography (HPLC) [29] using a 
BAS chromatograph (California, USA) with a Water 474 Fluorescence Detector. The fluorescence detection was performed using an excitation wavelength of $340 \mathrm{~nm}$ and an emission wavelength of $460 \mathrm{~nm}$.

2.6. Chemical Computation of Amino Acids to Mesquite. To determine the chemical count of the mesquite protein concentrate, the method proposed by Marrugo et al. [30, 31] was followed, which consisted of dividing the number of essential amino acids present in the protein concentrates by the number of essential amino acids in the standard protein and multiplying this value by one hundred.

2.7. Evaluation of the Protein Quality Index of Mesquite. This value was calculated for the concentrates under study by applying the method proposed by Frota et al. [32] and Sarmiento et al. [26]. This consisted of dividing the protein requirement recommended by the $\mathrm{FAO}$ by the requirement of the most limiting amino acid of the protein under study. Similarly, for the calculation of the protein requirement recommended by the FAO at a given age, the methods proposed by the aforementioned authors were used, where the requirement of the most limiting amino acid indicated in the ideal protein proposed by the $\mathrm{FAO} / \mathrm{WHO}$ was divided by the amount of limiting amino acid of the protein being evaluated $[33,34]$.

2.8. Data Processing and Analysis. Data was collected from bibliographic references of the research background and laboratory data from the physicochemical and biochemical analysis of the concentrates, and the results were tabulated in Microsoft Excel 2010 spreadsheets. The calculations were carried out in triplicate and the results were expressed as the mean \pm standard deviation.

\section{Results and Discussion}

3.1. Chemical Composition of Mesquite. Table 1 shows crude fiber, ash, moisture, and carbohydrate contents of mesquite. According to the data obtained in Table 1, the protein content of mesquite was like those of other legumes such as soybeans [33], which demonstrates the potential of this legume in the preparation of plant-based foods with high protein content or as a substitute for meat products. It is also important to highlight the importance of developing research where the biological value and the type of proteins present in it are indicated [26].

The protein values (in mesquite concentrate) were higher than those reported by Ugwuona and Suwaba [31] for protein concentrates of sword beans (Canavalia ensiformis) with a $49.5 \%$ protein content. On the other hand, lower protein values were recorded in mesquite concentrate than those reported by Ghribi et al. [35] for chickpea (Cicer arietinum L.) concentrates. Regarding the fiber content, mesquite concentrate showed substantially lower values than soybean concentrate. These results for mesquite were like those presented by Betancur-Ancona et al. [36], who reported the same value in ancho beans (Phaseolus lunatus). The fat contents of protein concentrates for both mesquite and soybean were low, compared to those of the studies con-
TABle 1: Chemical composition of mesquite.

\begin{tabular}{lc}
\hline Physicochemical properties & Composition (\%) \\
\hline Total protein & $67.9 \pm 0.3$ \\
Fat & $0.8 \pm 0.1$ \\
Crude fiber & $1.9 \pm 0.4$ \\
Ash & $4.3 \pm 0.1$ \\
Moisture & $0.9 \pm 0.4$ \\
Carbohydrates & $24.2 \pm 1.1$ \\
\hline
\end{tabular}

Values are presented as mean \pm standard deviation $(n=3 \times 2)$.

ducted by Cruz-Gracida [37] for carob bean (Prosopis laevigata) concentrate and by Ghribi et al. [35] for chickpea concentrate.

Although the digestibility of mesquite concentrate was not measured in this study, there are studies such as that of Mamone et al. [25] which found that the germ meal of this legume is highly digestible in the gastrointestinal tract, releasing significant amounts of free amino acids.

3.2. Amino Acid Profile of Mesquite. The amino acid composition of mesquite proteins is shown in Table 2. Leucine, methionine + cysteine, phenylalanine + tyrosine, tryptophan, and histidine contents had the highest values. Threonine was not detected in the concentrate.

The amino acid profile showed evident nutritional potential of mesquite. Comparing the data obtained in our study with those reported by Deak et al. [33], the amino acids leucine, methionine + cysteine, phenylalanine + tyrosine, tryptophan, valine, and histidine are found in higher proportions in mesquite compared to soybean, with differences of $26.50 \mathrm{mg} / 100 \mathrm{~g}, 41.40 \mathrm{mg} / 100 \mathrm{~g}, 20.30 \mathrm{mg} / 100 \mathrm{~g}$, $14.30 \mathrm{mg} / 100 \mathrm{~g}, 1.20 \mathrm{mg} / 100 \mathrm{~g}$, and $39.20 \mathrm{mg} / 100 \mathrm{~g}$, respectively. Concerning amino acids such as isoleucine, lysine, and threonine, their content was higher in soybeans. According to our data, mesquite concentrate did not contain threonine, so it is necessary to mix different legumes such as soybeans to obtain concentrate with complete protein content.

Compared to other legumes, e.g., peas [38], the amino acid content of mesquite was higher in those analyzed in this study and the protein content was like those of concentrates such as peas. However, care must be taken with these comparisons, as the amino acid and protein content of legumes may change according to the variety [39].

It should be noted that histidine, one of the amino acids with the highest concentration in mesquite concentrate, is considered essential during infancy. This leads us to consider the use of concentrate as a possible therapeutic food [40].

Interesting aspects were found in this research regarding the essential amino acid content of mesquite and soy protein concentrates concerning the amino acid requirements in different age groups according to $\mathrm{FAO} / \mathrm{WHO} / \mathrm{UN}$. In the case of isoleucine, mesquite had a slightly lower content than that found in soy concentrate and was like what is required by infants ( $4.6 \mathrm{mg} / 100 \mathrm{~g}$ of protein). But it was higher than what 
TABLE 2: Essential amino acid profile of mesquite concentrate.

\begin{tabular}{lc}
\hline Essential amino acid & Content $(\mathrm{mg} / 100 \mathrm{~g}$ of protein $)$ \\
\hline Isoleucine & $4.6 \pm 2.1$ \\
Leucine & $34.4 \pm 0.7$ \\
Lysine & $4.4 \pm 1.7$ \\
Methionine + cysteine & $47.0 \pm 0.8$ \\
Phenylalanine + tyrosine & $38.1 \pm 0.9$ \\
Threonine & Not detected \\
Tryptophan & $15.9 \pm 1.4$ \\
Valine & $6.2 \pm 0.8$ \\
Histidine & $45.6 \pm 0.5$ \\
\hline
\end{tabular}

Values are presented as mean \pm standard deviation $(n=3 \times 2)$. Analysis was performed by HPLC (high-performance liquid chromatography).

is required by other age groups such as children from 2 to 5 years old, school children from 10 to 12 years old, and adults, with percentage differences of $39 \%, 39 \%$, and $72 \%$, respectively.

The leucine content found in mesquite concentrate was 4 times higher than that reported for soy concentrate. Regarding the age groups of infants, children, school children, and adults, it was found that the contents for this amino acid were up to $3,5,12$, and 18 times higher, respectively, than what is recommended by FAO. This means that the daily requirements of this amino acid would be completely covered by using mesquite concentrate in starchy products for mass consumption. This trend was similar for amino acids such as methionine, tryptophan, and histidine since the standard requirements reported by FAO for these three amino acids range for infants from $17 \mathrm{mg} / 100 \mathrm{~g}$ to $42 \mathrm{mg} /$ $100 \mathrm{~g}$ of protein, for children from $11 \mathrm{mg} / 100 \mathrm{~g}$ to $25 \mathrm{mg} /$ $100 \mathrm{~g}$ of protein, for school children from $9 \mathrm{mg} / 100 \mathrm{~g}$ to $22 \mathrm{mg} / 100 \mathrm{~g}$ of protein, and for adults from $5 \mathrm{mg} / 100 \mathrm{~g}$ to $16 \mathrm{mg} / 100 \mathrm{~g}$ of protein.

3.3. Chemical Computation of Essential Amino Acids in Mesquite. Chemical computations of mesquite protein concentrate for the preschool age study from 2 to 5 years old are shown in Table 3. This calculation is a parameter for measuring the quality of protein in the diet, based on the composition of essential amino acids of the concentrates under study (Table 2) and the standard or ideal protein according to FAO/WHO/UN. The values established for each essential amino acid were isoleucine $(2.8 \pm 0.0)$, leucine $(6.6 \pm 0.0)$, lysine $(5.8 \pm 0.0)$, methionine + cysteine $(2.5 \pm 0.0)$, phenylalanine + tyrosine $(6.3 \pm 0.0)$, threonine $(3.4 \pm 0.0)$, tryptophan $(1.1 \pm 0.0)$, and valine $(3.5 \pm 0.0)$. According to the results obtained, those amino acids that are found in greater proportion or in a relationship of inverse proportion between the value of the amino acid in the study concentrate and the protein standard would be better. According to the above, methionine + cysteine and tryptophan were the amino acids with dispositions to supply the requirements for the ideal protein proposed by $\mathrm{FAO} /$ WHO/UN.
TABLE 3: Chemical computation and score on the composition of essential amino acids in mesquite protein concentrate.

\begin{tabular}{lcc}
\hline Essential amino acid & Chemical computation & Chemical score \\
\hline Isoleucine & $1.6 \pm 0.8$ & $0.6 \pm 0.1$ \\
Leucine & $5.2 \pm 0.1$ & $0.2 \pm 0.1$ \\
Lysine & $0.8 \pm 0.3$ & $1.3 \pm 0.0$ \\
Methionine + cysteine & $18.8 \pm 0.3$ & $0.1 \pm 0.0$ \\
Phenylalanine & $6.0 \pm 0.1$ & $0.2 \pm 0.5$ \\
+ tyrosine & Not detected & Not detected \\
Threonine & $14.4 \pm 1.4$ & $0.1 \pm 0.0$ \\
Tryptophan & $1.8 \pm 0.3$ & $0.6 \pm 0.1$ \\
Valine &
\end{tabular}

Values are presented as mean \pm standard deviation $(n=3 \times 2)$.

The chemical score is an index of protein quality, which is measured inversely to the chemical computation, since the analysis is based on the relationship between the ideal proteins for comparison, in this case, the preschool protein and the studied protein. In this work, the chemical scores for the mesquite protein concentrate studied were inverse to the chemical computation in its determination ratio.

The mesquite protein concentrate satisfied the essential amino acid requirements for this group according to the $\mathrm{FAO} / \mathrm{WHO} / \mathrm{UN}$ ideal protein. In general, mesquite could be useful in the design of foods with high protein content and, in turn, could supply the amino acid needs of other foods. However, due to its low content of some amino acids that are present in other legumes such as soybeans, it would be ideal to make mixtures of these types of vegetables to ultimately obtain foods with high nutritional content, especially protein.

Sarmiento et al. [26] and Díaz-Batalla et al. [41] functionally characterized mesquite flour to include it in a food matrix as a protein extender. Similarly, the functional properties of mesquite protein concentrate obtained by different methods for possible use as a food ingredient reported by Jaimes-Morales [24] can be evidenced.

3.4. Evaluation of the Protein Quality Index of Concentrate of Mesquite. Table 4 shows the protein quality index and protein scores of mesquite in preschool children and adults, respectively. For their determination, a relation with the amino acid and protein requirements according to $\mathrm{FAO} /$ WHO recommendations had to be made. The established values were for preschoolers between 2 and 5 years of age in $1 \mathrm{~g}$ of ideal protein and whose amino acid values in $\mathrm{mg}$ were isoleucine $(28 \mathrm{mg})$, leucine $(66 \mathrm{mg})$, lysine $(58 \mathrm{mg})$, methionine + cysteine $(25 \mathrm{mg})$, phenylalanine + tyrosine (63 mg), threonine (34 mg), tryptophan (11 mg), valine (35 $\mathrm{mg})$, and histidine $(19 \mathrm{mg})$. For adults, the ideal protein value was $0.75 \mathrm{~g}$, whose amino acid values were isoleucine (13 mg), leucine (19 mg), lysine (16 mg), methionine + cysteine $(17 \mathrm{mg})$, phenylalanine + tyrosine $(19 \mathrm{mg})$, threonine (9 $\mathrm{mg})$, tryptophan $(5 \mathrm{mg})$, valine $(13 \mathrm{mg})$, and histidine (16 mg). 
TABLe 4: Protein quality index and score of mesquite concentrate.

\begin{tabular}{lccc}
\hline $\begin{array}{l}\text { Essential amino } \\
\text { acid }\end{array}$ & $\begin{array}{c}\text { Amino acid composition } \\
(\mathrm{mg} / \mathrm{g})\end{array}$ & $\begin{array}{c}\text { Protein intake score of child requirements } \\
(\mathrm{g} / \mathrm{kg} / \mathrm{d})\end{array}$ & $\begin{array}{c}\text { Protein intake score of adult requirements } \\
(\mathrm{g} / \mathrm{kg} / \mathrm{d})\end{array}$ \\
\hline Isoleucine & 46 & 0.61 & 0.28 \\
Leucine & 344 & 0.19 & 0.06 \\
Lysine & 44 & 1.32 & 0.36 \\
Methionine & 470 & 0.05 & 0.04 \\
+ cysteine & & & \\
Phenylalanine & 381 & 0.16 & 0.05 \\
+ tyrosine & Not detected & Not detected & Not detected \\
Threonine & 159 & 0.07 & 0.03 \\
Tryptophan & 62 & 0.56 & 0.21 \\
Valine & 456 & 0.04 & 0.04 \\
Histidine & & &
\end{tabular}

The protein quality index was calculated as the ratio of the protein requirement of the $\mathrm{FAO} / \mathrm{WHO} / \mathrm{UN}$ recommended standard for an age group in $\mathrm{g} / \mathrm{kg} / \mathrm{d}$ divided by the score of the most limiting amino acid value of the required protein intake of the studied protein multiplied by $100 \%$. The protein intake score of the amino acid requirement of the studied protein was obtained by dividing the $\mathrm{mg}$ of amino acid of the FAO ideal protein by the $\mathrm{mg}$ of the respective amino acid of the studied protein.

The nutritional quality of a protein depends primarily on its ability to meet essential amino acid requirements. Nitrogen and amino acid demands are the most logical measures for predicting the quality of a protein. Mesquite met the amino acid requirements for adults except for the sulfur amino acids for cysteine and aromatic amino acids. When calculating the protein quality index of the concentrates for preschoolers, it was observed that the protein of the soy concentrate had a higher protein quality index compared to the protein of the mesquite concentrate. The values also indicated that both concentrates exceeded the amino acid requirements by more than $100 \%$, according to the $\mathrm{FAO} /$ WHO ideal protein. The valine content found in mesquite was $63 \mathrm{mg} / 100 \mathrm{~g}$ of protein, which was $19 \%$ higher than that reported for soy concentrate. Likewise, it was $11 \%$ higher than that reported in the recommended daily requirement for infants and $44 \%$ higher than the recommended daily requirement for children. The content of this amino acid in mesquite was up to 3 and 4 times higher $[24,36]$ for school children and adults.

When calculating the protein quality index of the concentrates studied for adults, it was observed that the mesquite concentrate was $208 \%$. These values also indicated that both concentrates exceeded the amino acid requirements by more than $100 \%$, according to the $\mathrm{FAO} / \mathrm{WHO} /$ UNU ideal protein.

\section{Conclusions}

According to our results, mesquite should be considered as a suitable alternative in the development of foods with high nutritional quality. Also, from an economic perspective, our study considered the use of legumes such as mesquite in the development of sustainable agricultural productivity in production areas and where there are possibly vulnerable populations in a state of malnutrition due to poor access to food. However, it is important to highlight the need to test the digestibility of mesquite protein to assess its protein quality more accurately.

The protein concentrate of mesquite, due to its nutritional characteristics in terms of protein content, available protein, chemical computation, and protein quality index, could offer possible nutritional enrichment when incorporated in certain types of food, since it covers the requirements of essential amino acids for adults (exceeding 31\% of the protein required for this age group) and it fulfills with equal conditions the requirements of other amino acids in the other age groups.

\section{Data Availability}

The data used to support the findings of this study are available from the corresponding author upon request.

\section{Conflicts of Interest}

All authors declare that they have no conflict of interest.

\section{Acknowledgments}

The authors acknowledge financial support from Universidad de Cartagena through the plan for the strengthening and sustainability of research groups recognized and classified by the Ministry of Science (Minciencias) from Colombia, administrative decision 01430/2019.

\section{References}

[1] S. Gbashi, O. Adebo, J. A. Adebiyi et al., "Food safety, food security and genetically modified organisms in Africa: a current perspective," Biotechnology and Genetic Engineering Reviews, vol. 37, no. 1, pp. 30-63, 2021.

[2] N. A. George and F. H. McKay, "The public distribution system and food security in India," International Journal of 
Environmental Research and Public Health, vol. 16, no. 17, p. $3221,2019$.

[3] M. M. Weigel, R. X. Armijos, M. Racines, and W. Cevallos, "Food insecurity is associated with undernutrition but not overnutrition in Ecuadorian women from lowilncome urban neighborhoods," Journal of Environmental and Public Health, vol. 2016, Article ID 8149459, 15 pages, 2016.

[4] F. Siddiqui, R. A. Salam, Z. S. Lassi, and J. K. Das, "The intertwined relationship between malnutrition and poverty," Frontiers in Public Health, vol. 8, p. 453, 2020.

[5] The State of Food Security and Nutrition in the World 2020, State Food Security and Nutrition World 2020, 2020, [cited 2021 Sep 6]. Available from: https://data.unicef.org/ resources/sofi-2020/.

[6] A. Ali and D. B. Rahut, "Healthy foods as proxy for functional foods: consumers' awareness, perception, and demand for natural functional foods in Pakistan," International Journal of Food Science, vol. 2019, 12 pages, 2019.

[7] Growing at a Slower Pace, World Population Is Expected to Reach 9.7 Billion in 2050 and Could Peak at Nearly 11 Billion Around, UN DESA, United Nations Department of Economic and Social Affairs, 2019, https://www.un.org/development/ desa/en/news/population/world-population-prospects-2019 .html.

[8] O. B. Cano, S. C. Morales, and C. Bendtsen, "Covid-19 modelling: the effects of social distancing," Interdisciplinary Perspectives on Infectious Diseases, vol. 2020, Article ID 2041743, 7 pages, 2020.

[9] N. H. Shah, A. H. Suthar, and E. N. Jayswal, "Control strategies to curtail transmission of COVID-19," International Journal of Mathematics and Mathematical Sciences, vol. 2020, Article ID 2649514, 12 pages, 2020.

[10] Y. Y. Yang, S. Ma, X. X. Wang, and X. L. Zheng, "Modification and application of dietary fiber in foods," Journal of Chemistry, vol. 2017, Article ID 9340427, 8 pages, 2017.

[11] N. A. Sagar, A. Khar, Vikas, A. Tarafdar, and S. Pareek, "Physicochemical and thermal characteristics of onion skin from fifteen Indian cultivars for possible food applications," Journal of Food Quality, vol. 2021, Article ID 7178618, 11 pages, 2021.

[12] H. J. Njura, K. I. Kubai, S. T. Taaliu, and K. Shem Khakame, "The relationship between agricultural teaching approaches and food security in Kenya," Education Research International, vol. 2020, Article ID 8847864, 18 pages, 2020.

[13] T. Louro, C. Simões, W. Lima et al., "Salivary protein profile and food intake: a dietary pattern analysis," Journal of Nutrition and Metabolism, vol. 2021, 10 pages, 2021.

[14] FAO, Pulses: Nutritions Seeds for Sustainable Future, The Food and Agriculture Organization, 2016, http://www.fao.org/3/ai5528e.pdf.

[15] L. Yegrem, "Nutritional composition, antinutritional factors, and utilization trends of Ethiopian chickpea (Cicer arietinum L.)," Journal of Food Science, vol. 2021, article 5570753, pp. 1-10, 2021.

[16] M. Banovic, A. Arvola, K. Pennanen et al., "Foods with increased protein content: a qualitative study on European consumer preferences and perceptions," Appetite, vol. 125, pp. 233-243, 2018.

[17] G. Zhao, C. Zhou, and F. Fan, "Preparation and properties of soy protein isolate/cotton-nanocrystalline cellulose films," International Journal of Polymer Science, vol. 2021, Article ID 5518136, 7 pages, 2021.
[18] P. Felker, N. Grados, G. Cruz, and D. Prokopiuk, "Economic assessment of production of flour from Prosopis alba and P. pallida pods for human food applications," Journal of Arid Environments, vol. 53, no. 4, pp. 517-528, 2003.

[19] U. Gonzales-Barron, R. Dijkshoorn, M. Maloncy et al., "Nutritive and bioactive properties of mesquite (Prosopis pallida) flour and its technological performance in breadmaking," Foods, vol. 9, no. 5, p. 597, 2020.

[20] C. E. de Souza Nascimento, C. A. da Silva, I. R. Leal et al., "Seed germination and early seedling survival of the invasive speciesProsopis juliflora(Fabaceae) depend on habitat and seed dispersal mode in the Caatinga dry forest," Peer J, vol. 8, article e9607, 2020.

[21] M. E. Rodríguez Araujo, D. R. Pérez, and G. L. Bonvissuto, "Seed germination of five Prosopis shrub species (FabaceaeMimosoideae) from the Monte and Patagonia phytogeographic provinces of Argentina," Journal of Arid Environments, vol. 147, pp. 159-162, 2017.

[22] M. A. M. Sadeq, M. S. Abido, A. A. Salih, and J. A. Alkhuzai, "The effects of mesquite (Prosopis juliflora) on soils and plant communities in the deserted rangelands of Bahrain," International Journal of Forestry Research, vol. 2020, Article ID 8810765, 8 pages, 2020.

[23] A. A. Comole, P. W. Malan, and M. A. P. Tiawoun, "Effects of Prosopis velutina invasion on soil characteristics along the riverine system of the Molopo River in north-west province, South Africa," International Journal of Ecology, vol. 2021, Article ID 6681577, 11 pages, 2021.

[24] J. Jaimes-Morales, "Evaluation of the functional properties of Prosopis juliflora protein concentrate obtained by different methods," International Journal of Engineering and Technology, vol. 9, no. 5, pp. 3841-3847, 2017.

[25] G. Mamone, L. Sciammaro, S. De Caro et al., "Comparative analysis of protein composition and digestibility of_Ceratonia siliqua_ L. and _Prosopis_ spp. seed germ flour," Food Research International, vol. 120, pp. 188-195, 2019.

[26] A. C. F. Sarmiento, W. J. R. Echavarría, A. M. T. Espinosa, E. A. M. Mera, and E. ACT, "Physicochemical and functional characterization of trupillo flour (Prosopis juliflora (Sw.) DC) and its inclusion in a food matrix," INGE CUC, vol. 17, no. 2, 2021.

[27] S. E. I. Elbehairi, A. E. Ahmed, A. A. Alshati et al., "Prosopis juliflora leave extracts induce cell death of MCF-7, HepG2, and LS-174T cancer cell lines," EXCLI Journal, vol. 19, pp. 1282-1294, 2020.

[28] "Official methods of analysis of AOAC International (Archivo de computadora, 2003)," https://www.worldcat.org/title/ official-methods-of-analysis-of-aoac-international/oclc/ 476567963.

[29] M. Araya, S. García, J. Rengel, S. Pizarro, and G. Álvarez, "Determination of free and protein amino acid content in microalgae by HPLC-DAD with pre-column derivatization and pressure hydrolysis," Marine Chemistry, vol. 234, article 103999, 2021.

[30] A. M. L. Yesid, M. M. C. Piedad, and D. L. Marlene, "Nutritional Evaluation of Concentrated Protein of Phaseolus lunatus and Vigna unguiculata," Información tecnológica, vol. 27, no. 6, pp. 107-114, 2016.

[31] F. U. Ugwuona and S. Suwaba, "Effects of defatted jack bean flour and jack bean protein concentrate on physicochemical and sensory properties of bread," Nigerian Food Journal, vol. 31, no. 2, pp. 25-32, 2013. 
[32] K. D. Frota, L. A. Lopes, I. C. Silva, and J. A. Arêas, "Nutritional quality of the protein of Vigna unguiculata L. Walp and its protein isolate," Rev Ciência Agronômica, vol. 48, no. 5, pp. 792-798, 2017.

[33] N. A. Deak, L. A. Johnson, E. W. Lusas, and K. C. Rhee, "Soy protein products, processing, and utilization," Soybeans, vol. 1, pp. 661-724, 2008.

[34] S. Tabtabaei, D. Konakbayeva, A. R. Rajabzadeh, and R. L. Legge, "Functional properties of navy bean (Phaseolus vulgaris) protein concentrates obtained by pneumatic triboelectrostatic separation," Food Chemistry, vol. 283, pp. 101$110,2019$.

[35] A. M. Ghribi, A. Sila, R. Przybylski et al., "Purification and identification of novel antioxidant peptides from enzymatic hydrolysate of chickpea (Cicer arietinum L) protein concentrate," Journal of Functional Foods, vol. 12, pp. 516-525, 2015.

[36] D. Betancur-Ancona, S. Gallegos-Tintoré, and L. Chel-Guerrero, "Wet-fractionation ofPhaseolus lunatus seeds: partial characterization of starch and protein," Journal of the Society of Chemical Industry, vol. 84, no. 10, pp. 1193-1201, 2004.

[37] M. Cruz-Gracida, S. Siles-Alvarado, L. L. Méndez-Lagunas, S. Sandoval-Torres, J. Rodríguez-Ramírez, and G. BarriadaBernal, "Quantitative analysis of fatty acids in Prosopis laevigata flour," Grasas y Aceites, vol. 70, no. 3, pp. 321-e321, 2019.

[38] B. Çabuk, M. G. Nosworthy, A. K. Stone et al., "Effect of fermentation on the protein digestibility and levels of nonnutritive compounds of pea protein concentrate," Food Technology and Biotechnology, vol. 56, no. 2, pp. 257-264, 2018.

[39] M. A. M. Mune, S. R. Minka, I. L. Mbome, and F. X. Etoa, "Nutritional potential of bambara bean protein concentrate," Pakistan Journal of Nutrition, vol. 10, no. 2, pp. 112-119, 2011.

[40] A. M. de Souza, A. F. Silva, D. F. B. Campeche, J. F. B. Melo, A. T. S. dos Santos, and L. V. O. Vidal, "Corn substitution by mesquite bean flour (Prosopis juliflora) maintains growth and improves protein metabolism of Nile tilapia juveniles (Oreochromis niloticus)," Tropical Animal Health and Production, vol. 53, no. 4, pp. 1-15, 2021.

[41] L. Díaz-Batalla, J. P. Hernández-Uribe, R. Gutiérrez-Dorado et al., "Nutritional characterization of Prosopis laevigata legume tree (mesquite) seed flour and the effect of extrusion cooking on its bioactive components," Foods, vol. 7, no. 8, p. $124,2018$. 